\title{
DIAKRONIKA
}

Vol. 17 No. 1 Th. 2017 p: 46-58

ISSN: 1411-1764 (Print) | 2620-9446 (Online)

http://diakronika.ppj.unp.ac.id

\section{Membangun Wawasan Sejarah Lokal Siswa Dengan Penguatan Scaffolding Dalam Pembelajaran Sejarah}

\author{
Piki Setri Pernantah \\ pikisetripernantah@gmail.com \\ Universitas Sebelas Maret
}

\begin{abstract}
History provides a valuable lesson. There are many diffecences, contradictions, and complex events that lead us to the gates of freedom. Therefore, teaching history in schools could be something very important. The current and furure challenge is on how we were able to fix all the problems occurred all this time in history lesson. The teacher should also be able to make history lesson to be more interesting, such as internalizing local history into the history lesson at schools so that the students are able to get close to reality and are not forgeting their local history. Building the students' insight about local history with scaffolding reinforcement so that the students can develop their local historical insight optimally. Local history can serve as a source of ancestral history that should be preserved. In other words, local history can be a well that is never dry in drought, the values of wisdom for the realization of the ideals of a nation that is balanced, both physically and mentally. It adds to the material wealth of history and foster interest and knowledge of students in learning history. Therefore, this paper is intended to explain how the strategy to build students' insight of local history with scaffolding reinforcement in teaching history at schools
\end{abstract}

Keywords: local history, scaffolding, the teaching of history

Abstrak

Sejarah memberikan pelajaran yang amat berharga. Betapa banyak perbedaan, pertentangan, dan peristiwa sejarah bangsa yang begitu kompleks mengantarkan bangsa Indonesia ke gerbang kemerdekaan. Oleh karena itu, pembelajaran sejarah di sekolah dapat menjadi sesuatu yang sangat penting. Tantangan saat ini dan ke depannya, bagaimana kita mampu memperbaiki segala persoalan yang terjadi selama ini dalam pembelajaran sejarah. Guru juga harus mampu menjadikan pembelajaran sejarah menjadi lebih menarik, seperti menginternalisasikan sejarah lokal ke dalam pembelajaran sejarah di sekolah agar mampu membuat para siswa dekat dengan kenyataan dan tidak melupakan sejarah lokal. Membangun wawasan siswa tentang sejarah lokal dengan penguatan scaffolding memungkinkan siswa dapat mengembangkan wawasan sejarah lokal yang dimilikinya secara optimal. Sejarah lokal dapat berfungsi sebagai salah satu sumber sejarah leluhur yang perlu dilestarikan.

Dengan kata lain, sejarah lokal bisa menjadi sumur yang tak kunjung kering di musim kemarau panjang yang penuh dengan nilai-nilai kebijaksanaan bagi 
Piki Setri Pernantah

Membangun Wawasan Sejarah Lokal Siswa Dengan Penguatan Scaffolding Dalam

Pembelajaran Sejarah

perwujudan cita-cita bangsa. Wawasan mengenai sejarah lokal akan memperkaya materi pelajaran sejarah dan menumbuhkan minat siswa dalam belajar sejarah. Tulisan ini mencoba menguraikan bagaimana strategi untuk membangun wawasan sejarah lokal siswa dengan penguatan scaffolding dalam pembelajaran sejarah di sekolah.

Kata Kunci: sejarah lokal, scaffolding, pembelajaran sejarah

This work is licensed under the Creative Commons Attribution-Share Alike 4.0 International License.

\section{Pendahuluan}

Bangsa Indonesia adalah bangsa "Bhineka Tunggal Ika" yang berarti walaupun berbeda-beda tetapi pada hakikatnya bangsa Indonesia tetap satu juga. Hal itu menunjukkan bahwa bangsa Indonesia memiliki identitas kebudayaan yang beragam. Dimensi keberagaman adalah wujud dari integrasi pluralitas yang telah menjadi karakter utama dari bangsa Indonesia. Salah satu konsekuensi dari aspek pluralitas masyarakat Indonesia adalah dalam bentuk transformasi sejarah lokal melalui wadah pendidikan sebagai sebuah alternatif untuk kembali membangun kemandirian dan identitas bangsa di era globalisasi sekarang ini.

Dewasa ini pembicaraan tentang sejarah lokal dalam mendukung kemajuan bangsa Indonesia tengah menjadi perhatian. Sejarah lokal diartikan sebagai sejarah daerah tertentu (local history). Sejarah lokal juga merupakan bagian dari sejarah nasional, sebab bangsa ini terdiri dari berbagai lokalitas atau multi-locality yang memiliki visi misi yang sama sehingga menjadi kesatuan bangsa. Adanya sejarah nasional tidak terlepas dari pengaruh sejarah lokal masyarakat berbagai daerah di Indonesia. Semangat lokal dari berbagai lokalitas hadir untuk kemajuan nasional. Selain itu, sejarah lokal juga dapat dimaknai sebagai peristiwa sejarah yang berkenaan dengan tatanan kehidupan sosial, politik, budaya, maupun ekonomi masyarakat lokal. Saat ini sejarah lokal mulai terabaikan oleh sebagian masyarakat lokal itu sendiri. Masih banyak masyarakat yang tidak mengetahui dan memahami sejarah lokal daerahnya masing-masing. Padahal sejarah lokal dapat menjadi bagian penting dalam membangun jati diri bangsa, terutama identitas masyarakat lokal setempat.

Menggali dan membangun kembali wawasan sejarah lokal melalui pendidikan dapat dikatakan sebagai resolusi atau gerakan kembali pada basis nilai budaya dan sejarah lokal sendiri sebagai upaya membangun identitas bangsa, serta menjadi filter dalam menyeleksi pengaruh budaya luar. Sejarah lokal itu meniscayakan fungsi yang strategis bagi pembentukan karakter, menumbuhkan nasionalisme dan penguat identitas lokal maupun nasional. 
Pendidikan sejarah lokal yang menaruh perhatian pada pembentukan identitas lokal dan nasional akan bermuara pada munculnya sikap yang mandiri, penuh inisiatif, dan kreatif.

Di sekolah saat ini, salah satu mata pelajaran yang menjadi pusat perhatian adalah mata pelajaran sejarah. Dalam kurikulum 2013, mata pelajaran sejarah dikategorikan sebagai salah satu mata pelajaran wajib (sejarah Indonesia) di samping sebagai mata pelajaran peminatan (sejarah). Ini menunjukkan betapa pentingnya pembelajaran sejarah dalam membantu terwujudnya tujuan pendidikan nasional. Kochar (2008) menjelaskan bahwa sejarah telah lama menduduki posisi yang penting di antara berbagai mata palajaran yang diajarkan di berbagai tingkat pendidikan di sekolah.

Hal-hal yang sering terjadi di lapangan dalam pembelajaran sejarah adalah masih terdapat guru mengajarkan materi yang jauh dari realitas kehidupan siswa. Siswa dihadapkan pada serentetan catatan fakta-fakta yang terjadi di masa lampau. Materi sejarah diajarkan dalam bentuk kronik (cerita tentang fakta-fakta) sehingga membuat pembelajaran sejarah terkesan kaku dan monoton serta dianggap membosankan oleh sebagian siswa. Hal itu menjadi salah satu faktor siswa mengalami kesulitan dalam belajar sejarah.

Kemampuan bercerita juga sangat ditentukan oleh kemampuan berimajinasi dan beretorika. Apabila hal ini tidak bisa dilakukan akan mengakibatkan materi pembelajaran sejarah menjadi kurang menarik. Pembelajaran sejarah menjadi kering, terkesan seolah-olah sumber sejarah bukanlah kenyataan yang bisa dirasakan atau dicermati dari lingkungan sekitar. Pembelajaran sejarah akan bertambah runyam manakala materi pelajaran terlalu bertumpu pada uraian yang ada dalam buku teks. Salah satu cara untuk mendekatkan siswa pada materi sejarah dan membuat pembelajaran sejarah menjadi lebih menarik adalah melalui sumber-sumber sejarah lokal dimana siswa tinggal. Pembelajaran sejarah dapat diperkaya dengan berbagai ragam sejarah lokal yang dimiliki oleh masyarakat daerah tersebut. Sejarah lokal tersebut tidak hanya diajarkan sebatas pengetahuan belaka atau hanya sekedar selingan di dalam pembelajaran sejarah. Namun, diharapkan sejarah local juga mampu menanamkan nilai-nilai lokal dalam membentuk jati diri siswa di sekolah.

Berdasarkan Permendikbud RI No. 65 tahun 2013 tentang Standar Proses Pembelajaran dijelaskan bahwa proses pembelajaran pada satuan pendidikan diselenggarakan secara interaktif, inspiratif, menyenangkan, menantang, dan memotivasi peserta didik untuk berpartisipasi aktif, serta memberikan ruang yang cukup bagi prakarsa, kreativitas, dan kemandirian sesuai dengan bakat, minat, dan perkembangan fisik serta psikologis peserta 
didik. Jika berpegang pada Permendikbud RI No.65 tahun 2013, mengisyaratkan tentang pentingnya penerapan pendekatan pembelajaran yang berpusat pada siswa. Begitupun dalam pembelajaran sejarah, diharapkan siswa jauh lebih aktif membangun wawasan sejarahnya dan mampu menjalankan pembelajaran sesuai dengan standar proses kurikulum 2013.

Penguasaan guru tentang pembelajaran sejarah dengan penguatan scaffolding ini tampaknya menjadi sangat penting agar siswa dapat mengembangkan wawasan sejarah lokal yang dimilikinya secara optimal. Penguatan scaffolding menjadi sangat penting karena masih terlihat siswa banyak yang belum memahami sejarah lokal daerahnya. Oleh karena itu diperlukan adanya penguatan dan pembimbingan oleh guru untuk mencapai tujuan agar terbangun wawasan sejarah lokal siswa.

Sejarah lokal berarti “sejarah dari suatu tempat”, suatu locality, yang batasannya ditentukan oleh penulis sejarah. Batasan geografisnya dapat berupa suatu tempat tinggal suku bangsa. Batasan geografis tersebut dapat mencakup dua-tiga daerah administratif tingkat dua atau tingkat satu dan juga dapat pula suatu kota, atau suatu desa. Sejarah lokal secara sederhana dapat dirumuskan sebagai kisah masa lampau dari kelompok-kelompok masyarakat yang berada pada suatu daerah geografis yang terbatas (Abdullah, 2010). Penulis mempunyai kebebasan menentukan batasan penulisannya, apakah mencakup geografis maupun etnis dalam skala yang luas ataupun sempit. Sejarah lokal bersifat elastis, bisa berbicara mengenai suatu desa, kecamatan, kabupaten, tempat tinggal suatu etnis atau suku bangsa pada suatu daerah atau beberapa daerah.

Penulisan sejarah lokal memiliki makna yang penting baik bagi kepentingan akademis dan pembangunan masyarakat, terutama kepentingan masyarakat dalam mempelajari pengalaman masa lalu nenek moyangnya. Hal ini sejalan dengan yang diungkapkan Langbein \& Lichtman, (1978) :

"local history conducted for their own sake, local history conduct to test hypotheses about broader jurisdictions, usually nation states, and local history that focus on understanding the process by which communities grow and develop. Although analytically distinct, in actual practise these lines frequently crisscross and run together."

Berbicara tentang sejarah lokal, ada hal penting yang menjadi titik perhatian bersama. Masyarakat lokal seyogyanya memiliki identitas dan solidaritas yang khas, sehingga penulisan sejarah lokal dapat menggambarkan spirit dan kekuatan yang lahir dari masyarakat lokal itu sendiri. Materi sejarah 
lokal dapat berbicara terkait peristiwa-peristiwa yang memiliki hubungan kausalitas dengan sejarah nasional ataupun peristiwa-peristiwa khas lokal yang tidak berhubungan dengan peristiwa sejarah nasional atau yang lebih luas sekalipun. Priyadi (2015) mengemukakan bahwa ruang sejarah lokal merupakan lingkup geografis yang dapat dibatasi sendiri oleh sejarawan dengan alasan yang dapat diterima semua orang.

Dalam batasan temporal/waktu dalam sejarah lokal, penulis dapat membuat batasan dari waktu tersingkat maupun terpanjang. Sebagai contoh, penulisan tentang pemberontakan PETA, bisa dibuat dalam rentang waktu yang pendek maupun panjang. Hal inilah yang memungkinkan sejarah lokal dapat ditulis oleh siapa saja. Para guru atau penulis dimanapun dapat berpartisipasi dalam penulisan sejarah lokal tentang peristiwa sejarah di daerah masing-masing melalui kerjasama dengan sejarawan akademis di perguruan tinggi.

Secara garis besar corak studi dan penulisan sejarah lokal yang telah dilakukan tentang Indonesia menurut Abdullah (2010) dapat dibedakan menjadi empat karakteristik, yakni : Studi yang difokuskan pada suatu peristiwa tertentu (studi peristiwa khusus/evenemental l'evenement).Studi yang lebih menekankan pada struktur.Studi yang berfokus pada perkembangan aspek tertentu dalam kurun waktu tertentu (tematis).

Studi sejarah umum yang menguraikan perkembangan daerah tertentu (provinsi, kota/ kabupaten dari masa ke masa).Keempat corak ini tidaklah bersifat eksklusif. Suatu corak bisa mengandung unsur-unsur corak yang lain. Corak ini lebih ditentukan oleh unsur dominan.

Scaffolding merupakan suatu pembelajaran dimana siswa diberi sejumlah bantuan selama tahap-tahap awal pembelajaran dan kemudian mengurangi bantuan tersebut dan memberikan kesempatan kepada siswa atau pelajar tersebut untuk mengambil alih tanggung jawab belajar yang semakin besar setelah mampu mengerjakannya sendiri (Gasong, 2007). Selain itu, (Subakti, 2010) juga berpendapat bahwa scaffolding merupakan bantuan yang diberikan kepada siswa untuk belajar dan untuk memecahkan masalah. Bantuan tersebut dapat berupa petunjuk, dorongan, peringatan, uraian masalah, langkah-langkah pemecahan, pemberian contoh, dan tindakantindakan lain yang memungkinkan siswa untuk belajar mandiri.

Dalam proses pembelajaran, pembentukan makna dalam diri siswa membutuhkan dukungan dari guru dalam bentuk topangan (scaffolding). Topangan adalah bantuan yang diberikan dalam wilayah perkembangan terdekat (zone of proximal development) siswa. Topangan diberikan berdasarkan apa yang bermakna bagi siswa. Dengan demikian apa yang 
sebelumnya belum dapat dimaknai sendiri oleh siswa, sekarang dapat bermakna berkat topangan itu. Dengan demikian, topangan diberikan kepada siswa dalam situasi yang interaktif, dalam arti guru memberikan topangan berdasarkan interpretasi mengenai apa yang bermakna bagi siswa. Siswa mengalami perkembangan dalam proses pembentukan makna berkat topangan itu.

Konstruksi scaffolding terjadi pada siswa yang tidak dapat mengartikulasikan atau menjelajahi belajar secara mandiri. Penguatan Scaffolding dipersiapkan oleh pem-belajar untuk tidak mengubah sifat atau tingkat kesulitan dari tugas, melainkan dengan penguatan Scaffoldingyang disediakan memungkinkan siswa agar berhasil menyelesaikan tugas belajarnya.

Penggunaan scaffolding adalah pemberian bantuan kepada siswa yang lebih terstruktur pada awal pelajaran secara bertahap dan kemudian menghilangkan tanggung jawab belajar pada siswa untuk bekerja atas arahan diri mereka sendiri (Nur \& Wikandari, 2000). Sebagai contoh, siswa diarahkan agar dapaat membuat pertanyaan sendiri tentang materi pemberontakan PRRI di Sumatera Barat atau disebut keterampilan bertanya. Dalam hal ini, pada awalnya guru dapat memberikan contoh-contoh pertanyaan, tetapi selanjutnya memberikan kesempatan kepada siswa untuk membuat pertanyaan- pertanyaan tersebut.

Secara sederhana, pembelajaran Scaffolding dapat diartikan sebagai suatu teknik pemberian dukungan belajar secara terstruktur, yang dilakukan pada tahap awal untuk mendorong siswa agar dapat belajar secara mandiri. Model pembelajaran Scaffolding adalah suatu bentuk model pembelajaran yang bersifat kooperatif. Dalam pembelajaran Scaffolding bimbingan diberikan oleh guru kepada siswa dalam proses pembelajaran dengan persoalan-persoalan terfokus dan interaksi yang bersifat positif. Pemberian bimbingan dan dukungan belajar tidak dilakukan secara terus menerus, tetapi seiring dengan terjadinya peningkatan kemampuan siswa secara berangsurangsur, guru kemudian mengurangi dan melepaskan siswa untuk belajar secara mandiri. Jika siswa belum mampu mencapai kemandirian dalam belajarnya, guru kembali ke sistem dukungan untuk membantu siswa memperoleh kemajuan sampai mereka benar-benar mampu mencapai kemandirian. Dengan demikian, esensi dan prinsip kerjanya tampaknya tidak jauh berbeda dengan scaffolding dalam konteks mendirikan sebuah bangunan. Pembelajaran Scaffolding sebagai sebuah teknik bantuan belajar (assisted-learning) dapat dilakukan pada saat siswa merencanakan, melaksanakan dan merefleksi tugas-tugas belajarnya. 
Mata pelajaran sejarah adalah mata pelajaran yang menanamkan pengetahuan, sikap, dan nilai mengenai proses perubahan dan perkembangan masyarakat Indonesia dan dunia dari masa lampau hingga masa kini. Mata pelajaran sejarah juga memiliki arti strategis dalam pembentukan watak dan peradaban bangsa yang bermartabat serta pembentukan manusia yang memiliki rasa kebangsaan dan rasa nasionalisme. Pembelajaran sejarah seharusnya mampu mendidik siswa agar memiliki untuk high order thinking dan/atau reflektive thingking dalam mempelajari dan memaknai setiap peristiwa sejarah agar mereka mampu meningkatkan kesadaran diri untuk menjadi pribadi good citizenship.

Pembelajaran sejarah juga dapat berfungsi untuk menyadarkan siswa akan adanya proses perubahan dan perkembangan masyarakat dalam dimensi waktu dan ruang untuk membangun perspektif serta kesadaran sejarah dalam memahami, menentukan, dan menjelaskan jati diri bangsa di masa lalu, masa kini, masa depan di tengah-tengah perubahan dunia. Pembelajaran sejarah juga berfungsi memberikan pengetahuan sejarah, tetapi juga memperkenalkan nilai-nilai luhur bangsa. Beberapa hal tersebut tidak akan memiliki arti bagi kehidupan siswa apabila siswa tidak memahami makna sejarah bangsanya.

Pembelajaran sejarah mempunyai sasaran yang ingin dicapai yaitu menjelaskan kepada siswa tentang perkembangan kehidupan manusia dari awal sampai perkembangan masa sekarang. (Kochar, 2008b) menyatakan bahwa sasaran utama pembelajaran sejarah adalah: (1) meningkatkan pemahaman terhadap proses perubahan dan perkembangan yang dilalui umat manusia hingga mampu mencapai tahap perkembangan yang sekarang; (2) meningkatkan pemahaman terhadap akar peradaban manusia dan penghargaan terhadap kesatuan dasar manusia; (3) menghargai berbagai sumbangan yang diberikan oleh semua kebudayaan pada peradaban manusia secara keseluruhan; (4) memperkokoh pemahaman bahwa interaksi saling menguntungkan bagi berbagai kebudayaan adalah faktor yang penting dalam kemajuan kehidupan manusia; (5) memberikan kemudahan kepada siswa yang berminat mempelajari sejarah suatu negara dalam kaitannya dengan sejarah umat manusia secara keseluruhan.

Pembelajaran sejarah dapat mengembangkan aktivitas siswa untuk melakukan telaah terhadap peristiwa-peristiwa. Pemahaman mengenai peristiwa diinternalisasi dalam diri sehingga melahirkan contoh untuk bersikap dan bertindak. Kartodirdjo (1992) menerangkan bahwa pengajaran sejarah berkedudukan sangat strategis dalam pendidikan nasional sebagai soko guru pembangunan bangsa. Pengajaran sejarah perlu disempurnakan agar dapat berfungsi lebih efektif, yaitu penyadaran warga negara dalam melaksanakan tugas dan kewajiban dalam pembangunan nasional. Pembelajaran sejarah 
akan mengembangkan aktivitas siswa untuk melakukan telaah berbagai peristiwa, untuk kemudian dipahami dan diinternalisasikan dalam diri sehingga melahirkan contoh untuk bersikap dan bertindak. Sejarah tidak hanya sebagai gambaran tentang masa lalu, namun juga sebagai cerminan untuk masa yang akan datang. Tujuan mempelajari sejarah ialah menjadi manusia yang berkepribadian kuat. Belajar sejarah tidak melulu memerlukan hafalan. Penekanan belajar sejarah lebih kepada mengerti sesuatu agar dapat menentukan sikap. Mempelajari sejarah adalah mempelajari riwayat tokohtokoh besar dengan maksud mencari teladan dan contoh.

Sebagaimana Aman (2011) juga mengemukakan tentang fungsi pembelajaran sejarah, yaitu (1) untuk membangkitkan minat kepada sejarah tanah airnya, (2) untuk mendapatkan inspirasi dari sejarah, (3) untuk memberi pola pikir ke arah berpikir rasional, kritis, dan empiris, (4) mengembangkan sikap mau menghargai nilai-nilai kemanusiaan. Begitu pentingnya pembelajaran sejarah untuk negeri ini, sudah selayaknya para generasi muda memiliki wawasan sejarah yang baik, tidak terkecuali wawasan mengenai sejarah lokal di daerah masing-masing.

Idealnya pembelajaran sejarah harus berangkat dari masalah dan fenomena-fenomena lokal agar siswa mempunyai rasa memiliki dan membutuhkan pelajaran yang mereka terima. Tentu konsep pembelajaran sejarah yang ideal adalah pembelajaran yang mampu menyajikan materi kesejarahan yang dekat dengan lingkungan siswa. Hal itu dapat dilakukan melalui sajian materi sejarah lokal daerah masing-masing siswa dalam aktivitas pembelajaran di sekolah.

Pengajaran sejarah lokal memiliki peran penting dalam upaya menghadirkan peristiwa kesejarahan yang dekat dengan siswa. Sejarah lokal juga mampu menghadirkan berbagai fenomena, baik berkaitan dengan latar belakang keluarga, peranan pahlawan lokal dalam perjuangan lokal maupun nasional, kebudayaan lokal, asal-usul etnis, dan berbagai peristiwa yang terjadi di tingkat lokal. Siswa diajak untuk memahami realitas sejarah mulai dari tingkat lokal, hingga tingkat nasional, dan global agar para siswa dapat membangun wawasan sejarah lokal yang baik dan tidak melupakan sejarah daerahnya yang dapat menjadi identitas sejarah dan budaya yang patut dibanggakan.

Waktu yang terbatas dalam proses pembelajaran sejarah menjadi kendala agak sulit bagi penyajian sejarah lokal. Pengajaran sejarah lokal disajikan terpisah menjadi bagian tersendiri dalam proses pembelajaran. Keinginan guru agar para siswa memiliki wawasan sejarah lokal yang baik tentu akan sulit untuk dicapai. Oleh sebab itu, guru harus mampu mencarikan 
solusi agar siswa mampu membangun wawasan sejarah lokal dengan keterbatasan waktu. Butuh peran penting dari guru menanggapi hal ini agar siswa dapat memahami sejarah lokal dengan baik.

Pembelajaran sejarah sudah seharusnya memperkuat materi sejarah yang terkait dengan lokalitas setempat. Sehingga pengajaran topik sejarah lokal untuk membangun wawasan sejarah lokal siswa dapat dilakukan dengan beberapa cara. Pertama, melalui penyisipan pada beberapa topik sejarah nasional yang mempunyai korelasi dengan peristiwa lokal. Contoh pelajaran tentang peristiwa tentang revolusi kemerdekaan, pendidik yang di Sumatera Barat, menonjolkan peranan Pemerintahan Darurat Republik Indonesia (PDRI). Kedua, melalui studi khusus melalui kajian pustaka, museum, maupun situs peninggalan sejarah. Hal ini dapat dilakukan persemester untuk mengenalkan sejarah dan budaya masyarakat setempat. Ketiga, melalui teamteaching, guru IPS bisa melakukan kolaborasi untuk membahas masalah-masalah lokal secara interdisiplin dalam aspek sejarah. Pengajaran sejarah lokal di sekolah juga perlu menghadirkan realitas fenomena pada lokal daerah yang lain. Hal ini sangat penting dalam upaya mengerti dan berempati dengan keberagaman budaya lain.

Salah satu solusi yang dapat dilakukan oleh guru: mengembangkan wawasan sejarah lokal agar siswa mampu memiliki wawasan sejarah lokal adalah dengan memberikan penguatan scaffolding dalam pembelajaran sejarah di sekolah. Informasi-informasi sejarah yang bersifat lokal disajikan guru secara efektif agar dapat dipahami oleh para siswa. Para siswa diberikan bantuan dan dibimbing secara terus menerus, tetapi seiring dengan terjadinya peningkatan kemampuan siswa, secara berangsur-angsur guru harus mengurangi dan melepas siswa untuk belajar secara mandiri.

Jika siswa belum mampu mencapai kemandirian dalam memahami sejarah lokal, guru kembali ke sistem dukungan untuk membantu siswa memperoleh kemajuan sampai mereka benar-benar mampu mencapai kemandirian dan mampu meningkatkan wawasan sejarah lokal.Contoh, proses pembelajaran sejarah di kawasan Sumatera Barat dapat menekankan materi sejarah yang berkaitan dengan kawasan lokal Sumatera Barat. Salah satu materi dapat dikembangkan, yakni materi perkembangan islam di Indonesia. Guru juga dapat membangun wawasan sejarah lokal mengenai topik islamisasi di Minangkabau. Minangkabau kental dengan budaya islam, terlihat dari filosofis hidup orang Minangkabau, "Adat Basandi Syarak, Syarak Basandi Kitabullah" (Adat bersendikan syariat Islam, Syariat bersendikan AlQur'an). Falsafah hidup yang senantiasa selalu digunakan dalam kehidupan sehari-hari dalam masyarakat Minangkabau, tentu memiliki proses sejarah yang panjang sehingga hari ini menjadi falsafah adat Minangkabau. 
Penghulu (2001) mengemukakan bahwa sebelum agama islam masuk ke Minangkabau, adat Minangkabau mengikuti ketentuan-ketentuan alam sehingga mucul falsafah “alam takambang jadi guru.". Setelah Islam masuk ke Minangkabau, falsafah adat itu disempurnakan oleh agama islam, maka sumber dasar adat Minangkabau berada pada derajat pertama, karena agama Islam dalam kitab suci Al-Qur'an banyak menyatakan bahwa alam ini merupakan ayat Allah, yang dapat dipelajari oleh manusia yang berakal. Hal itu menunjukkan bahwa proses islamisasi pernah terjadi di Minangkabau hingga menjadi landasan penting dalam hidup orang Minangkabau hingga hari ini. Selain itu, materi mengenai wawasan sejarah lokal tentang Minangkabau juga bisa ditekankan pada aspek kajian bahwa Minangkabau beserta adat istiadatnya terbagi dalam dua fase, yaitu fase sebelum masuknya Islam dan setelah masuknya Islam.

Materi pembelajaran sejarah tentang proses islamisasi tersebut dapat dikembangkan untuk wilayah Sumatera Barat. Siswa yang di awal belum memahami proses sejarah lokal itu secara benar dan utuh, memerlukan penguatan scaffolding atau bimbingan dari guru agar dapat membangun wawasan sejarah lokalnya sehingga menimbulkan kesadaran identitas dan sejarah.

Semua hal itu direalisasikan dalam proses pembelajaran sejarah. Berikut disajikan perencanaan kegiatan siswa dalam membangun wawasan sejarah lokal melalui pembelajaran dengan menggunakan penguatan scaffolding.

\section{Kegiatan Pendahuluan}

1. Siswa siap mengikuti kegiatan pembelajaran sejarah lokal.

2. Siswa mempelajari materi yang pelajaran sejarah lokal.

3. Siswa aktif menjawab pertanyaan dari guru.

4. Siswa dibagi dalam kelompok-kelompok diskusi.

Kegiatan Inti

1. Siswa berdiskusi tentang materi proses islamisasi di Indonesia dan Minangkabau dalam kelompok masing-masing.

2. Siswa saling membantu dalam kelompok untuk menyelesaikan tugas kelompok.

3. Siswa berpartisipasi aktif dalam diskusi kelompok dan mengajukan pertanyaan-pertanyaan.

4. Siswa memberikan tanggapan dan masukan.

5. Siswa menyimak penjelasan dari guru. 


\section{Kegiatan Penutup}

1. Siswa menyimpulkan hasil diskusi proses islamisasi di Indonesia dan Minangkabau.

2. Siswa mengumpulkan hasil kerja kelompok kepada guru.

Selain adanya aktivitas dari para siswa, guru berperan sebagai fasilitator dan penanggungjawab kelas agar tujuan dan proses pembelajaran tercapai dengan baik. Diperlukan perencanaan kegiatan atau aktivitas yang seharusnya dilakukan dalam mengembangkan metode ini. Berikut bentuk perencanaan kegiatan guru untuk membangun wawasan sejarah lokal dalam proses pembelajaran sejarah dengan menggunakan penguatan scaffolding, yaitu:

Kegiatan Pendahuluan

1. Guru mengkondisikan siswa untuk belajar dan memotivasi siswa terkait dengan semangat islamisasi.

2. Guru menjelaskan tujuan pembelajaran yang akan dicapai oleh para siswa.

3. Guru memberikan apersepsi (bertanya kepada siswa tentang proses islamisasi di Indonesia, khususnya Minangkabau) dan me-review materi sebelumnya.

Kegiatan Inti

1. Guru memberikan tugas untuk dikerjakan bersama kelompok.

2. Guru memberikan bantuan berupa petunjuk, dorongan, peringatan, menguraikan masalah ke dalam langkah pemecahan, memberi contoh dan tindakan yang memungkinkan siswa untuk belajar mandiri.

3. Guru meminta siswa untuk mempresentasikan hasil diskusi kelompok terkait proses islamisasi di Indonesia dan Minangkabau.

4. Guru memberikan komentar, pertanyaan atau tangggapan jawaban siswa dalam proses diskusi kelompok.

5. Guru memberikan kesempatan bertanya kepada siswa terkait materi yang didiskusikan.

Kegiatan Penutup

1. Guru membimbing siswa untuk menyimpulkan materi yang dipelajari.

2. Guru memberikan tugas rumah terkait materi yang belum dipahami oleh siswa.

Demikianlah bentuk perencanaan kegiatan siswa dan guru dalam pembelajaran sejarah untuk membangun wawasan sejarah lokal dengan penguatan scaffolding. Para guru sejarah, dapat mengadopsi perencanaan 
tersebut sebagai suatu acuan dalam pengembangan wawasan sejarah lokal siswa. Terlihat aktivitas guru dalam melakukan proses pembimbingan secara bertahap tanpa harus melupakan bahwa siswa juga harus mampu belajar secara mandiri tanpa bantuan dari gurunya.

\section{Simpulan}

Berdasarkan uraian di atas dapat dikemukakan bahwa pembelajaran sejarah lokal perlu dikembangkan di sekolah, untuk menarik minat siswa dalam belajar sejarah dan mempertahankan wawasan sejarah lokal tetap ada dalam pemikiran para siswa. Guru juga harus mampu menjadikan pembelajaran sejarah menjadi lebih menarik, menginternalisasikan sejarah lokal ke dalam pembelajaran sejarah di sekolah agar mampu membuat para siswa dekat dengan kenyataan dan tidak melupakan sejarah lokal daerahnya. Membangun wawasan siswa tentang sejarah lokal dengan penguatan Scaffolding dalam mengembangkan wawasan sejarah lokal yang dimiliki siswa secara optimal.

Mengembangkan wawasan sejarah lokal dengan penguatan Scaffolding dapat dilakukan dengan cara memberikan bantuan dan bimbingan secara terus menerus, tetapi seiring dengan terjadinya peningkatan kemampuan siswa, secara berangsur-angsur guru harus mengurangi dan melepas siswa untuk belajar secara mandiri. Jika siswa belum mampu mencapai kemandirian dalam memahami sejarah lokal, guru kembali ke sistem dukungan untuk membantu siswa memperoleh kemajuan sampai mereka benar-benar mampu mencapai kemandirian. Selain itu, juga sudah dipapakan bagaimana aktivitas siswa dan guru dalam proses pembelajaran sejarah untuk membangun wawasan sejarah lokal dengan penguatan scaffolding.

\section{Daftar Rujukan}

Abdullah, T. (2010). Sejarah Lokal di Indonesia. Yogyakarta: Gadjah Mada University Press.

Aman. (2011). Model Evaluasi Pembelajaran Sejarah. Yogyakarta: Ombak.

Gasong, D. (2007). Model pembelajaran konstruktivistik sebagai alternatif mengatasi masalah pembelajaran. Retrieved from Http;/puslit. petra. ac. id/journal s/intrior

Kartodirdjo, S. (1992). Pendekatan ilmu Sosial dalam Metodologi Sejarah, Jakarta: PT. Jakarta: Gramedia Pustaka Utama.

Kochar, S. K. (2008a). Pembelajaran Sejarah, Penerjemah Purwanta dan Yovita Hardiwati. Jakarta: PT Gramedia Widiasarana Indonesia.

Kochar, S. K. (2008b). Pembelajaran Sejarah "Teaching of History". Jakarta: PT Gramedia Widiasarana Indonesia.

Langbein, L. I., \& Lichtman, A. J. (1978). Ecological inference. Sage 
Publications.

Nur, M., \& Wikandari, P. R. (2000). Pengajaran berpusat kepada siswa dan pendekatan konstruktivis dalam pengajaran. Surabaya: Unesa.

Penghulu, I. H. D. R. (2001). Rangkaian mustika adat basandi syarak di Minangkabau. Bandung: Remaja Rosdakarya.

Priyadi, S. (2015). Sejarah Lokal Konsep, Metode, dan Tantangannya. Yogyakarta: Ombak.

Subakti, Y. . (2010). Paradigma Pembelajaran Sejarah ber-basis Konstruktivisme. SPSS, 24. 